\title{
Lixo, racismo e injustiça ambiental na Região Metropolitana de Belém
}

\author{
Waste, racism and environmental injustice \\ in the Metropolitan Region of Belém
}

Rosane Maria Albino Steinbrenner [I] Rosaly de Seixas Brito [II] Edna Ramos de Castro [III]

\section{Resumo}

A lógica da produção e de descarte de resíduos sólidos é expressão das mais perversas e paradoxais da desigual distribuição de poder no capitalismo. Estigmatiza com a ideia de "atraso", de "indesejáveis", indivíduos e lugares "descartáveis", que recebem os resíduos e os riscos a eles associados que a sociedade de consumo produz. Ancorado em pesquisa documental e bibliográfica e em entrevistas abertas com moradores e ativistas envolvidos na luta pela retirada do Lixão de Marituba, como é conhecido o irregular e polêmico aterro da Região Metropolitana de Belém, este artigo focaliza e discute o caso - emblemático como cena colonial na contemporânea Amazônia urbana - a partir dos marcos da ecologia política e das noções de justiça ambiental, colonialidades, racismo e necropoder.

Palavras-chave: Lixão de Marituba; Amazônia urbana; colonialidades; necropoder; ecologia política.

\begin{abstract}
The logic of production and disposal of solid waste is one of the most perverse and paradoxical expressions of the unequal distribution of power in capitalism. It stigmatizes with the idea of "retrogression", of "undesirable" and "disposable" individuals and places, which receive the waste and the risks related to it produced by the consumer society. Grounded on documentary and bibliographic research and on open interviews with residents and activists involved in the struggle for the removal of the Marituba Dump, as the irregular and controversial landfill in the Metropolitan Region of Belém is known, the article focuses on and discusses the caseemblematic as a colonial scene in contemporary urban Amazonia - based on Political Ecology and on the notions of environmental justice, colonialities, racism and necropower
\end{abstract}

Keywords: Marituba Dump; urban Amazonia; colonialities; necropower; political ecology. 


\section{Introdução}

Desde os anos 1970, aprofundam-se uma encruzilhada ético-existencial e seus impactos socioambientais, com a crescente subordinação da sociedade contemporânea a um modelo de desenvolvimento desigual, de necessidades determinadas pelo mercado, consumo e descarte exacerbados e a produção generalizada do desperdício. ${ }^{1}$ A produção e o descarte de resíduos sólidos ${ }^{2}$ revelam-se, nesse cenário, como uma das expressões mais perversas da desigual distribuição de poder no capitalismo. Os ricos não só produzem mais resíduos como os empurram para as zonas mais pobres, onde vivem as populações historicamente mais vulneráveis e marginalizadas, naquilo que Acselrad (2002, p. 51) identifica como uma "injusta ordem ambiental". Afinal, como diz o autor, não é possível "separar os problemas ambientais da forma como se distribui desigualmente o poder sobre os recursos políticos, materiais e simbólicos".

Não surpreende, portanto, que metade do lixo global, cerca de 1,3 bilhão de toneladas anuais, seja produzida pelos países membros da OCDE, ${ }^{3}$ que respondem, por sua vez, por pouco mais de $20 \%$ da população mundial (World Bank, 2012), responsável pelo consumo de $60 \%$ de toda a matéria-prima do planeta. Na outra ponta da geração de resíduos sólidos urbanos ${ }^{4}$ (RSU), estão os países do Oriente Médio (6\%), Sul da Ásia (5\%) e África Subsariana (5\%), seguidos pelos da América Latina (12\%), justamente onde se concentram os 50 maiores lixões a céu aberto do mundo, destino final do descarte irregular e altamente poluente (Unep, 2015).

Figura 1 - Tratamento dos resíduos sólidos no Brasil e por região (2014)

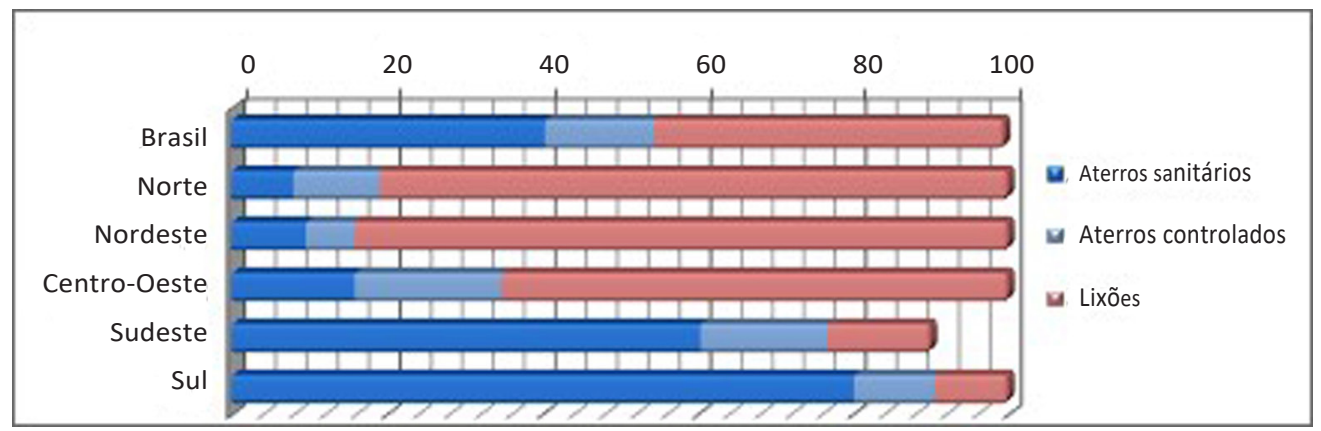

Fonte: adaptado pelas autoras de Alvarez (2014). 
No âmbito interno do Brasil, reproduz-se a desigualdade: enquanto as regiões Sul e Sudeste possuem as melhores condições de coleta e tratamento de resíduos, nas regiões Norte e Nordeste imperam os lixões, com índices acima de $80 \%$ de prevalência (Alvarez, 2014).

Por ser o lixo também uma construção cultural, seus efeitos não são apenas objetivos, de contaminação do ambiente e de ameaças à saúde coletiva, mas igualmente simbólicos (Douglas, 1966). Ele estigmatiza com a ideia de "atraso", de "sem valor" ou "indesejáveis", indivíduos e lugares historicamente "descartáveis" que, na versão atualizada da ocupação colonial dos espaços e dos corpos, recebem os resíduos e são expostos aos riscos que a sociedade de consumo produz.

Trata-se de evidente manifestação de racismo ambiental, expressão cunhada no final dos anos de 1980, nos Estados Unidos, nas lutas por direitos civis e nos estudos sobre a ausência de equidade geográfica na distribuição dos riscos ambientais (Acserald, Mello e Bezerra, 2009, p. 20), que apontavam clara intersecção entre as variáveis raça e renda, porém com imposição desproporcional "de rejeitos perigosos às comunidades de cor".

Nas regiões periféricas e mais pobres dos espaços globais ou locais, nas chamadas hiperperiferias (Torres e Marques, 2001) - lugares de segregações superpostas e cumulativas -, inscreve-se assim, de forma naturalizada, a precarização da vida em fronteiras claramente observáveis e definidas historicamente por uma hierarquização racializada da distribuição de reconhecimento, como diz Mbembe (2016), que determina quem deve ser protegido e quem deve morrer ou ser exposto ao risco de morte.

Na perspectiva da ecologia política, o presente artigo focaliza, como caso exemplar de assimetria socioambiental metropolitana, o Lixão de Marituba, como é conhecido o único aterro da Região Metropolitana de Belém $(\mathrm{RMB}),{ }^{5}$ a principal metrópole da porção oriental da Amazônia brasileira. Trata-se de um aterro privado, instalado com autorização do Estado à revelia da população e de forma irregular no município metropolitano com mais ocupações subnormais (áreas favelizadas) do País (Nadali, Krause e Lima Neto, 2014), próximo a moradias, rios e igarapés, vizinho de uma reserva ambiental e de uma comunidade quilombola secular. Cena contemporânea de uma invisível e complexa Amazônia urbana, que reflete a lógica das relações de poder do sistema capitalista moderno-colonial (Wallerstein, 1999), do qual são pilares de reprodução ampliada a classificação racializada dos sujeitos e a ideia antropocêntrica de dominação da natureza (Porto-Gonçalves, 2012, p. 19; Quijano, 2004).

Ancorado em pesquisa documental e bibliográfica e em entrevistas abertas com moradores e ativistas envolvidos na disputa em torno da luta coletiva pela retirada do Lixão, pretende-se discutir e ilustrar, em suas dimensões cotidianas e silenciosas, as noções de injustiça e racismo ambiental, como tratadas por Acserald, 2002; Acserald, Mello e Bezerra, 2009), dialogando com Fanon (2008) e Souza Santos (2019), e com o conceito de colonialidade do poder, de Quijano (2004), de necropolítica, de Mbembe (2011 e 2016), e de biopoder de Foucault (1999 e 2008). Com tal abordagem, busca-se delinear uma discussão conceitual em torno dos dissensos e assimetrias ante a destinação final dos resíduos sólidos na Região Metropolitana de Belém, no intuito de contribuir com o debate e a compreensão de um exemplar conflito socioambiental contemporâneo nas metrópoles e seus arredores. 
Antes buscaremos situar o caso do Lixão de Marituba, na seção que se segue, com seus antecedentes e contexto institucional, e a permanente reação popular à sua instalação e permanência na localidade, partindo-se de um conjunto de dados demográficos, geográficos e de indicadores sociais e econômicos (IBGE, 2010 e 2018; Ipea, 2010, 2015). 0 artigo trata também, ainda que não de forma exaustiva, das condições particulares da metropolização de Belém em sua relação com o processo de desenvolvimento imposto à Amazônia (Trindade Junior, 2000 e 2019; Becker, 2013; Castro, 2006).

\section{0 caso do lixão de Marituba}

O caso do Lixão de Marituba, como é conhecido o único aterro da Região Metropolitana de Belém (RMB), talvez não deva ser contado em uma cronologia linear até porque parece longe de terminar. Alguns fatos marcantes no desenrolar do caso reiteram o que apontou Polanyi (2000), que a desigualdade iria se tornar a grande batalha política do futuro, que é nosso presente, e que, sob a economia de mercado, a liberdade degenera em uma mera defesa da liberdade de empresa. Este o cerne da lógica de operação de um sistema que, como diz Acserald (2004), tende a não assumir responsabilidades pelas consequências de suas externalidades negativas, adotando na atualidade o discurso da "sustentabilidade" sem compromisso em alterar assimetrias, quando muito age apenas para mitigar os prejuízos que acarreta.

Em fevereiro de 2019, foi divulgado um estudo técnico-científico solicitado pela Secretaria de Meio Ambiente e Sustentabilidade do Pará (Semas) ao Instituto Evandro Chagas (IEC), ${ }^{6}$ que constatou a existência de anomalias na poeira domiciliar, nos solos e nas águas para consumo de nove comunidades próximas ao Lixão de Marituba (O Liberal, 2019), como é conhecida a Central de Processamento e Tratamento de Resíduos de Marituba, município da RMB. Licenciado pela Semas em 2012, o aterro é privado e é operado por duas empresas - Guamá Tratamento de Resíduos Ltda e Revita Engenharia S.A., do grupo nacional Solvi - maior grupo no setor de serviços ambientais do País, contratadas em caráter emergencial com dispensa de licitação pela prefeitura de Belém, em junho de 2015 (Diário Oficial, 2015). Na ocasião, era urgente, como detalharemos adiante, desativar o Lixão do Aurá, que durante mais de 20 anos funcionou no município de Ananindeua e recebeu de forma precária cerca de 1.400 toneladas diárias de resíduos sólidos produzidos na capital e região metropolitana, para assim atender tardiamente as determinações da Lei Nacional de Resíduos Sólidos.

Desde então, as empresas responsáveis pelo aterro na RMB respondem a cinco ações movidas pelo Ministério Público do Estado do Pará (MPPA) - duas delas tramitam no Poder Judiciário local por crimes ambientais; uma Ação Popular questiona o contrato com dispensa de licitação; e uma Ação Civil Pública refuta as licenças ambientais obtidas para operar 0 aterro. Uma delas, motivada pelos protestos da população e dos movimentos sociais especialmente contra o mau cheiro, deflagrou, em dezembro de 2017, uma operação, de nome Gramacho - em alusão ao maior lixão da América Latina - que levou, com a parceria da Polícia Civil, à prisão de gerentes operacionais e diretores nacionais da empresa e à 
Figura 2 - Mapa de localização do aterro sanitário de Marituba na RMB

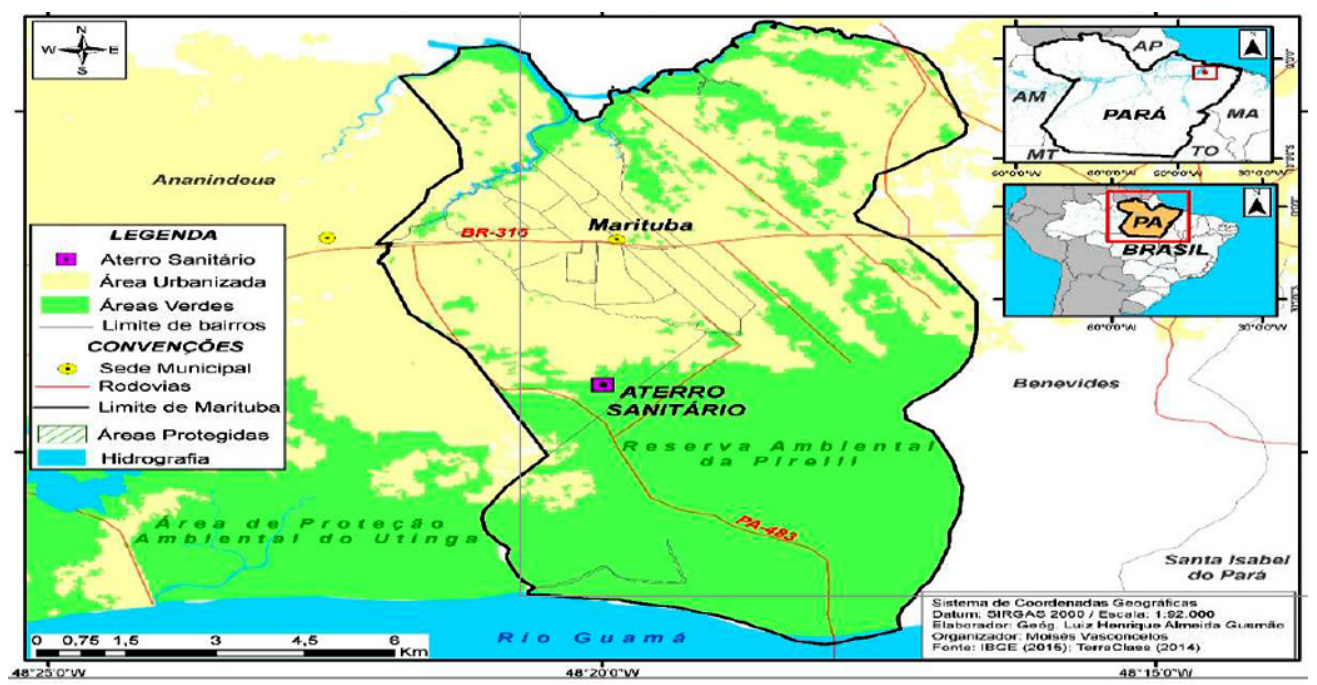

Fonte: Vasconcelos Junior e Corrêa (2017).

determinação de bloqueio de 53 milhões de reais para cobrir os danos ambientais causados (Portal - Pará, 2017a). Na ocasião, o inquérito policial incluía três denúncias-crime e mais de 30 autos de infração ambiental e procedimentos administrativos da Semas e inquérito policial da Delegacia do Meio Ambiente (Dema) em andamento contra o empreendimento. ${ }^{7}$

As empresas Guamá e Revita integram o rol de 50 empresas do grupo Solvi Participação S.A., com atuação no Brasil, Argentina, Peru e Bolívia. Em suas comunicações institucionais, o grupo defende valores como "sustentabilidade", "ética", integridade", "responsabilidade social". ${ }^{8}$ No ano de 2017, o grupo Solvi fechou o exercício financeiro com um resultado líquido de mais de 100 milhões de reais e um patrimônio líquido acima de 2 bilhões de reais (Solvi Participações, s/d, p. 26). No mesmo relatório de demonstrações financeiras, no item "Passivo contingente", o grupo Solvi e suas empresas aparecem como parte de 17 processos (civis, penais, trabalhistas), entre os quais os deflagrados pela operação Gramacho no Pará. No caso específico do Lixão de Marituba, entendem, conforme o documento, que "as denúncias carecem de comprovação probatória, portanto não foi constituída provisão contábil 
para fazer face a esse assunto" (ibid., p. 4). A empresa também afirma que teve todos os seus procedimentos licenciados pelo órgão competente, a Secretaria Estadual do Meio Ambiente (Semas) - Licença prévia em 2012; Licença de Instalação, em 2013; e de Operação, em 2014 - o que, entretanto, encontra-se sob questionamento judicial.

A mais recente das ações do Ministério Público do Pará, de fevereiro de 2020 (MMPA, 2020), e a quinta contra a empresa, investiga o que os movimentos sociais e ativistas ambientais denunciam, desde o início da implantação do aterro em Marituba: a suspeita de que a licença ambiental foi concedida indevidamente. Segundo o MPPA, "a empresa [Guamá] recebeu licenças para se instalar e funcionar mesmo tendo descumprido aspectos da legislação ambiental", como a "utilização de equipamentos adequados para o tratamento de resíduos e a adoção de providências para reduzir os impactos ambientais do aterro". O MPPA também já havia questionado e conseguido reverter a decisão do atual governo do estado de abrir mão da ação por danos morais e materiais ambientais que o estado move contra as empresas donas do aterro. "Pelo acordo, haveria extinção dessa ação, sem garantia ou qualquer contrapartida por parte da empresa para a sociedade atingida" (MPPA, 2019).

Também em 2017, com o aterro operando há cerca de dois anos, a prefeitura de Marituba, pressionada pelos movimentos sociais e ambientais, havia decretado "situação de emergência" no município (decreto n. 508/2017), ${ }^{9}$ em função dos danos sociais, ambientais e econômicos causados pelo aterro, entre os quais o documento destacava:

- o acúmulo de chorume, ${ }^{10}$ além da capacidade do sistema de drenagem do aterro, "sem qualquer tratamento", carreado para a microbacia hidrográfica do município;

- a ameaça ambiental, pelo chorume carreado para dentro da unidade de conservação de proteção integral Refúgio de Vida Silvestre Metrópole da Amazônia (Revis), rica em espécies endêmicas e considerada a segunda maior reserva florestal em área urbana do país;

- o "forte odor", sentido em vários bairros do município, oriundo das células de resíduos sólidos recobertas fora das normas técnicas;

- o aumento "gigantesco" de atendimento nas unidades de saúde, aumento de demandas de medicamentos;

- "grandes prejuízos econômicos" gerados pelo fechamento dos comércios, balneários (como são chamados na região locais de banho à beira de igarapés) e restaurantes nas proximidades do aterro;

- uma comunidade tradicional secular - a comunidade Quilombola do Abacatal - afetada diretamente tanto pelo forte odor como pelo chorume carreado para os cursos de água que abastecem e fornecem alimento aos seus moradores.

Durante todo o tempo, a empresa Guamá Tratamento de Resíduos negou a existência de irregularidades (Portal G1 - Pará, 2017b). Não obstante, na fala do pesquisador do Instituto Evandro Chagas, responsável pelo estudo técnico sobre a exposição de nove comunidades à contaminação por metais nos arredores do aterro sanitário, chamado Lixão de Marituba, chama a atenção a força probatória da contaminação.

Encontramos várias anomalias. Entre os mais nocivos: mercúrio, chumbo e manganês. Encontramos cobalto, elemento muito difícil de encontrar na água. Geralmente está associado a materiais 
condutores, como baterias e placas. Também identificamos cobalto na poeira (na parte mais externa, onde brincam as crianças) [...] no solo, destaco a presença de cobre em um nível muito alto (numa das comunidades mais próximas ao Lixão). O cobre está muito associado ao lixo. E esse é o maior indicador de que tem um problema com resíduos. (Pesquisador do IEC, Marcelo Lima, no Portal ORM, O Liberal, 5 fev 2019)

0 resultado, segundo o pesquisador, ainda não é conclusivo. Uma segunda etapa de verificação seria necessária para determinar a responsabilidade e a dimensão dos danos à saúde das pessoas e ao ambiente no entorno do aterro. Para isso, seriam necessários "recursos e nova solicitação da Semas". Até o momento, não há monitoramento regular e não há informação sobre a continuidade dos testes.

Nesse episódio, chamaram a atenção também o silêncio da grande imprensa e a ausência de repercussão sobre o resultado alarmante do estudo do Evandro Chagas. Situação similar já havia se revelado no episódio escandaloso da operação Gramacho. Com mandados de prisão cumpridos em vários Estados e a responsabilização de altos executivos de um grande grupo econômico nacional, a cobertura midiática do fato foi por fim acanhada, restringindo-se aos veículos locais e regionais.

Figura 3 - Imagem de passeata do movimento Fora Lixão

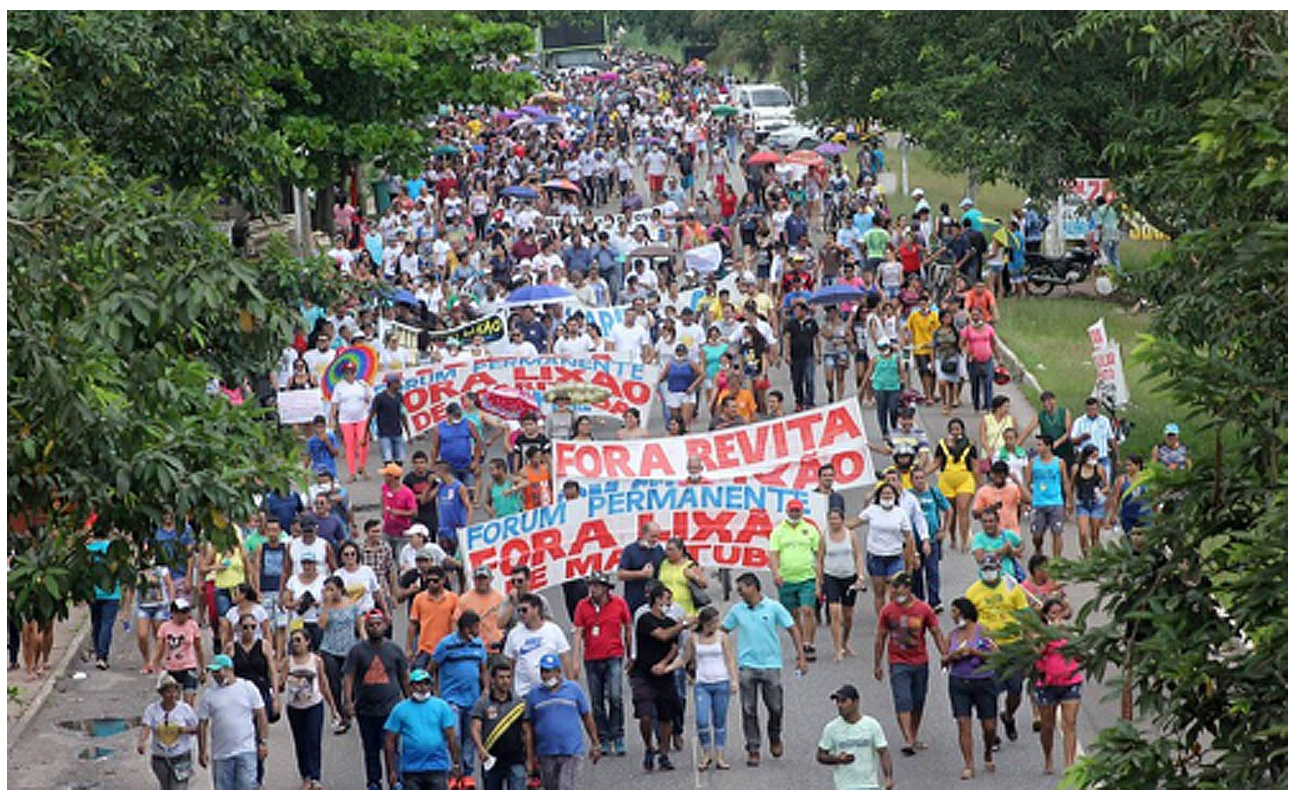

Fonte: site: https://foralixaomarituba.wixsite.com/foralixaomarituba 
Entre os atores relevantes no campo do conflito socioambiental do Lixão de Marituba, o de mais permanente atuação, com um papel estruturante da resistência, tem sido o movimento Fórum Permanente Fora Lixão, com o slogan "A resistência não pode parar enquanto o Lixão não fechar". Já, em 2011, quando as empresas iniciaram suas articulações junto ao município para implantar o que deveria ser um aterro sanitário, mas que se tornou um espaço de ameaças e conflitos socioambientais, um grupo de moradores começou um movimento nos moldes apontados por Svampa (2016). Em territórios latino-americanos caracterizados por fortes conflitos socioambientais, conforme a autora, há certos elementos comuns, entre os quais, uma nova fisionomia que assumem os movimentos socioambientais, rurais e urbanos. Neles, "desempenham um papel relevante diferentes coletivos culturais, certas ONGs ambientalistas - uma estrutura muitas vezes preexistente -, intelectuais e especialistas, que acompanham a ação de organizações e movimentos sociais" (ibid., p. 145).

0 movimento Fora Lixão de Marituba ${ }^{11}$ acabou, nesse sentido, por tecer, ao longo dos anos, uma rede de resistência formada por uma pluralidade de sujeitos envolvidos no combate aos danos socioambientais que a todos afetavam - trabalhadores e comerciantes locais, ativistas de causas ambientais, estudantes, pesquisadores e especialmente os moradores das proximidades do aterro. Em torno de uma causa coletiva, para que o município deixe de ser o destino do lixo da região metropolitana, a luta tem sido travada em diversos âmbitos: presencial, nos atos de rua, nas paralisações de trânsito, na participação em eventos, na pressão pela realização de audiências públicas; e não presencial, pelo uso intenso das redes sociais do movimento. Destaque-se a importância de um judiciário mais sensível às bandeiras ambientais e à defesa dos direitos humanos do movimento para a manutenção articulada da luta coletiva.

A ideia era conscientizar e integrar todas as pessoas afetadas e interessadas na luta, primeiramente pela não implantação do aterro e depois, quando voz vencida, pela retirada do empreendimento do município. "Não queremos adequação. $O$ que nós queremos é que o lixão seja encerrado e seja levado adequadamente para outro lugar, como não aconteceu aqui" explica uma integrante do movimento, representante de uma comunidade quilombola ancestral afetada. O Quilombo do Abacatal, com mais de 300 anos de existência, é formado por cerca de 120 famílias, que vivem basicamente da agricultura familiar e dependem do rio Uriboquinha, que o atravessa, para manter o seu modo de vida. Um dos cursos d'água que vem sendo seriamente afetados pelo vazamento do chorume.

Em maio de 2019, mais uma vez veio a público a crise permanente diante da ausência de uma política de resíduos sólidos para a Região Metropolitana de Belém (Portal G1, 2019). A empresa Guamá decidiu desativar o aterro de Marituba - o qual, diga-se, permanece irregular - por discordância nos valores pagos pela prefeitura de Belém. A prefeitura da capital anunciou, então, que reabriria o Lixão do Aurá. O Ministério Público impediu e concedeu novo prazo para que o aterro de Marituba continuasse operando e de forma adequada. Novos protestos de moradores e movimentos foram mobilizados contra a permanência do aterro no município. 0 prazo concedido na ocasião venceu e novo acordo judicial foi feito, permitindo que o aterro funcione até 2021. 
Até lá as prefeituras e o governo do estado terão que construir uma solução adequada para o destino dos resíduos produzidos pela RMB. De novo, o prazo é "improrrogável".

Para melhor dimensionar o caso e seus impactos, passamos, no tópico seguinte, a oferecer um apanhado de dados socioeconômicos e geográficos sobre o município de Marituba e a RMB, com destaque para a questão dos resíduos sólidos na região.

\section{A região e o município}

Marituba é um dos seis municípios que compõem, com a capital, a Região Metropolitana de Belém (RMB), localizada no Nordeste do estado do Pará, na porção oriental da Amazônia. Está situado na foz do rio Pará e é cortado por 30 cursos de água - rios e igarapés - formando uma grande área de várzea (Ipea, 2015). Com uma área de $4.600 \mathrm{~km}^{2}$, a RMB abriga cerca de 2,5 milhões de habitantes (FNEM, 2018), com uma taxa de urbanização acima de $95 \%$ e um total de 600 mil domicílios - $66 \%$ dos quais concentrados em Belém -, com ocupação frequente e histórica de áreas alagáveis e outras topograficamente mais baixas, submetidas a alagamentos regulares (Ipea, 2015). É, dentre as 26 regiões metropolitanas de capitais brasileiras, a com menor renda per capita ${ }^{12}$ e aquela com os maiores índices de ocupações subnormais em seus aglomerados urbanos (Nadalin, Krause e Lima Neto, 2014; Ipea, 2015).

O Índice de Bem Estar Urbano (Ibeu), desenvolvido pelo Observatório das Metrópoles (2016) e baseado em cinco indicadores - mobilidade urbana, condições ambientais, habitacionais, serviços coletivos e infraestrutura corrobora e complementa a percepção de que os municípios que constituem a Grande Belém conformam uma das mais pobres regiões metropolitanas do Brasil (Trindade Junior, 2019). A capital Belém aparece como a terceira de menor desempenho no conjunto do País, somente atrás de outras duas capitais da região Norte, Porto Velho e Macapá. Tal performance, com a de outras capitais do Nordeste, sinaliza, segundo o geógrafo Saint-Clair Trindade Junior, "o fato de que se trata de espaços metropolitanos cujo ritmo de crescimento demográfico e espacial não se faz acompanhar de melhorias substanciais de padrão de vida" (p. 147).

\begin{abstract}
A metrópole guarda certas peculiaridades em relação às condições de desenvolvimento impostas à Amazônia e ao seu processo interno de regionalização. Diferentemente de outras regiões em que a desconcentração metropolitana acompanha mais de perto o movimento do dinamismo econômico, configurando a metrópole polinucleada, a expansão aqui considerada reflete, acima de tudo, as condições de pobreza que caracterizam a mão de obra disponível no espaço amazônico. (Trindade Junior, 2000, p. 118)
\end{abstract}

O processo de urbanização da Amazônia, de forma geral, e de metropolização de Belém, em específico, inicia-se nos anos 1960. Belém nasceu do Forte do Presépio no século XVII, para ser a base da primeira fronteira capitalista com vistas a conquista, expansão e apropriação dos recursos naturais da região. Na década de 1960, com a abertura da Belém - Brasília, a urbanização avança, consolidando-se a partir dos anos 1970, como resultado das políticas de integração nacional e dos grandes projetos (Castro, 2006; Becker, 2013; Trindade Junior, 2019). Pela ação do Estado interventor, 
a colonização, dirigida ou espontânea, atraiu grande contingente de migrantes para as fronteiras de expansão do capital, ${ }^{13}$ populações em grande parte já excluídas de seus territórios de origem pelos processos de acumulação primária. Muitos voltaram das áreas de fronteira agrícola do interior da Amazônia - entendida tanto como lugar geográfico quanto fronteira e limite do humano (Martins, 2009) - para inchar os bairros periféricos de Belém, as vilas e distritos dos arredores e estabelecer novas relações marcadas pela desigualdade e pelo desequilíbrio, características da urbanização capitalista, em que, como entende Harvey (1980), desenvolvimento e não desenvolvimento seriam duas faces da mesma moeda. Assim, conforme explica Sirotheau (2019, p. 143), as cidades definem-se como "formas concentradoras de valores e igualmente responsáveis pela drenagem de valores de outras áreas, portanto, desestruturadoras por natureza".

\section{O município de Marituba}

Marituba, o menor dos municípios metropolitanos de Belém em termos territoriais, situa-se no centro da RMB, praticamente conurbado com Ananindeua e Belém e às margens do rio Guamá. Com uma população estimada em 129 mil habitantes (IBGE, 2018), funciona como cidade-dormitório da capital que, como toda a região, tem sua economia movida pelo setor de serviços. ${ }^{14}$ Possui alta precariedade urbana e de infraestrutura e uma população de baixa renda, $42 \%$ de seus domicílios possuem moradores com renda de até meio salário mínimo por pessoa (IBGE, 2010). Ocupa o primeiro lugar entre as cidades em área de abrangência metropolitana com maior incidência de aglomerados subnormais (AS), ${ }^{15}$ o que significa dizer que $77 \%$ da população de Marituba vive em assentamentos humanos em condições "inadmissíveis ao desenvolvimento social e urbano" (Nadali, Krause e Lima Neto, 2014, p. 75), popularmente conhecidos por favelas (Ipea, 2015).

Conforme o índice de vulnerabilidade social (IVS), ${ }^{16}$ Marituba possui alta vulnerabilidade social, especialmente quanto à dimensão infraestrutura, que inclui domicílios urbanos sem saneamento e sem serviço de coleta de lixo, apresentando os piores índices dentre os municípios da RMB. Desenvolvido pelo Ipea na perspectiva de sinalizar panoramas de vulnerabilidade e exclusão social, o IVS considera três dimensões ou subíndices - infraestrutura urbana, capital humano e renda e trabalho-, a partir da mensuração do acesso, da ausência ou da insuficiência de alguns ativos (Ipea, 2015), ou condições de vida, que deveriam estar à disposição de todo cidadão por força da ação do Estado.

O índice da vulnerabilidade social de Marituba vem melhorando - diminuiu em uma década de "muito alta" $(0,690)$, no ano 2000, para "alta" (0,455), em 2010 - assim como em grande parte da região Norte e Nordeste do País, porém seus municípios e regiões metropolitanas permanecem entre os piores cenários desenhados pelos estudos. Tampouco se altera a lógica histórica de segregação social. 0 IVS assim como o Índice de Desenvolvimento Humano (IDH) ${ }^{17}$ do município mostram - não como exceção, mas como regra ainda mais evidente em regiões de maior desenvolvimento diferenças emblemáticas quando consideradas as variáveis de cor e sexo (Gráfico 2). 
Gráfico 1 - IVS e IDHM do município de Marituba (RMB - PA) por cor e sexo
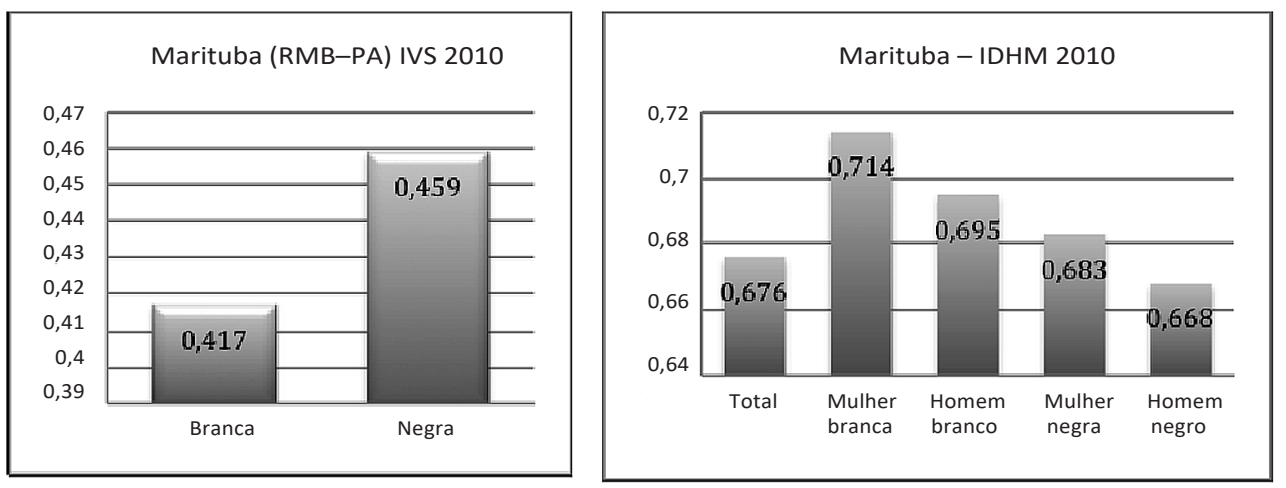

Fonte: elaborados pelas autoras. Ipea. Atlas de Vulnerabilidade Social (AVS) - http://ivs.ipea.gov.br

Saneamento e lixo

Do ponto de vista das condições de saneamento, são grandes as assimetrias entre os municípios (IBGE, 2010). Enquanto a rede de abastecimento de água atinge $75 \%$ dos domicílios da capital, em Ananindeua e Marituba essa oferta não chega a $40 \%$. Na coleta de esgoto e fossa séptica, as assimetrias agravam-se: em Belém, $68 \%$ dos domicílios são atendidos, enquanto, em Marituba, Benevides, Santa Bárbara e Santa Isabel do Pará, o serviço não atende nem $20 \%$ das residências.

No que diz respeito à coleta de resíduos sólidos, os indicadores são mais equilibrados (ibid.). Grande parte dos municípios da RMB possui serviço de recolhimento domiciliar regular, com índices todos próximos a 90\%, sendo Marituba, entretanto, o único a ultrapassar as duas cifras, com $11,06 \%$ da sua população sem serviço de coleta (conforme o IVS de 2010) 0 desafio, notadamente, são o destino e o tratamento do lixo produzido. A produção diária de resíduos sólidos domiciliares na Região Metropolitana de Belém é de 1.490 toneladas, das quais $69 \%$ são geradas pela capital (1.000 t/dia), 24\% por Ananindeua (350 t/dia), 2,7\% por Marituba (40 t/dia), 2,5\% por Santa Isabel (35 t/dia), 1,3\% por Benevides (20 t/dia) e 0,3\% por Santa Bárbara do Pará (5 t/dia). Os dados (Pereira, 2015) não consideram Castanhal, município anexado à RMB em 2011.

A Política Nacional de Resíduos Sólidos, aprovada em 2010 depois de mais de vinte anos de discussões no Congresso Nacional, foi enfática em instituir a responsabilidade compartilhada, da sociedade como um todo - cidadãos, governos, setor privado e sociedade civil organizada -, pela gestão ambientalmente correta dos resíduos sólidos. Para isso, iniciou, em 2011, a construção do Plano Nacional de Gestão de Resíduos Sólidos, aprovado no ano seguinte, que implica, no caso das regiões metropolitanas, o estímulo à criação de consórcios 
intermunicipais para integrar o atendimento às demandas regionais. A PNRS também determinou o encerramento de todos os lixões até 2014, prazo prorrogado até 2018.

Os municípios da Região Metropolitana de Belém, assim como a quase totalidade da Região Norte, com exceção de Rondônia e uma pequena porção de Tocantins, ainda não se adequaram à PNRS. Não desenvolveram plano intermunicipal integrado ou constituíram consórcio intermunicipal para a gestão de resíduos sólidos, como também são escassos os instrumentos de planejamento municipal (Brasil, 2017). O governo do estado do Pará elaborou seu Plano de Gestão Integrada de Resíduos Sólidos (Pergis) em 2014, porém, até o momento, não há informação de que tenha, de fato, saído do papel. A capital, Belém, aprovou seu Plano Municipal de Gerenciamento Integrado de Resíduos sólidos (lei ordinária n. 8899) em 2011, entretanto, na prática, o que impera é a ausência de políticas públicas e definições quanto ao destino e tratamento correto do lixo que produz.

Em 2015, pressionado pela nova Política Nacional de Resíduos Sólidos, o município de Belém fechou o Lixão do Aurá que por 23 anos funcionou no município de Ananindeua, de forma irregular, sem licença ambiental, recebendo o lixo produzido na RMB sem tratamento de chorume nem impermeabilização do solo, vertendo chorume e contaminando os cursos de água que formam a microbacia do rio Guamá (Matos et al., 2011). Nesse tempo, transformou em área de risco os principais mananciais de água da Grande Belém - lago Bolonha e Água Preta - situados a 1.400 metros do lixão, responsáveis por $65 \%$ do abastecimento de toda a população da região metropolitana. Em mais de duas décadas de operação desastrosa, o Lixão do Aurá teria sido responsável pela emissão de gases de efeito estufa (especialmente metano) em quantidade equivalente à queima de 34 mil hectares de floresta (UFPA, 2017). ${ }^{18}$

O Lixão do Aurá foi fechado, mas não encerrado. Até hoje não foi feita a remediação da área para recuperar os danos ambientais gerados. Segundo denúncias de movimentos sociais, o chorume continua vertendo. Também não foram atendidas as determinações da PNRS para a inclusão social-econômica dos catadores que atuavam na área do Aurá (cerca de 2 mil catadores). Por mais de uma vez, em 2014, quando se discutia o destino do Lixão, os catadores fecharam o trânsito na BR 316 para denunciar o descaso e reivindicar ações concretas. Na ocasião, junho de 2015 , cerca de 1,4 mil toneladas de resíduos sólidos urbanos mudaram de destino, os problemas, porém, só mudaram de endereço. Foram transferidos, como já vimos, para o município vizinho, Marituba. A lógica impositiva/punitiva, mais uma vez, iria se evidenciar na escolha do novo espaço, à revelia dos que ali vivem, denotando, como buscaremos discutir nos próximos dois tópicos, a lógica violenta e racializada dos mecanismos de injustiça ambiental que se impõe sobre corpos "descartáveis" e lugares pobres e periféricos. 


\section{Choque de territorialidades e luta pelo bem viver}

Estou vendo nossa comunidade sendo engolida pelo progresso. É o Lixão, o Linhão, o gasoduto, loteamento... (cercando nossa comunidade). Em 1987, derrubaram nossas casas com motosserra $e$ retroescavadeira e nós resistimos. (Representante da Comunidade Quilombola do Abacatal) ${ }^{19}$

Em vários sentidos, tanto do ponto de vista da natureza dos embates, quanto da configuração dos atores sociais envolvidos e, especialmente, da lógica de distribuição desigual de poderes no que tange à questão ambiental, o caso do Lixão de Marituba, até aqui descrito, não pode ser visto de maneira isolada. A fala acima, da representante da comunidade quilombola do Abacatal, ilustra de maneira inequívoca como se materializam a injustiça ambiental e os graves embates por ela gerados, ligados por uma linha invisível, já que resultam de uma mesma lógica de ocupação predatória e desigual do território. Em um cenário geopolítico de novas assimetrias entre o Norte e o Sul, nas últimas duas décadas houve intensa eclosão de conflitos socioambientais na América Latina, protagonizados por indígenas, camponeses e atores diversos no cenário urbano.

Em termos geopolíticos, a opção extrativista e a reprimarização da economia dos países latino-americanos, que exportam cada vez mais matérias-primas e disseminam, pelo seu território, enclaves de exportação, impuseram a cada um deles uma nova divisão territorial e do trabalho, caracterizada pela apropriação descontrolada dos recursos naturais não renováveis. Esse cenário, que atualiza o modelo desenvolvimentista de alto impacto e de base primária iniciado dos anos 1960/1970, colocou no cerne dos conflitos a luta por justiça ambiental, como discutiremos neste tópico.

Um novo ciclo de lutas delineou-se nos anos 2000 no continente, como aponta Svampa (2016). Emergiram, desde então, novos conflitos socioambientais rurais e urbanos, cuja composição social dos atores é distinta dos movimentos sociais tradicionais. Muitos desses movimentos são protagonizados por jovens e mulheres, que desempenham papel crucial nas suas estruturas organizativas.

Trata-se do que a autora denomina giro ecoterritorial das lutas. "O horizonte coletivo das lutas e a geração de um diagnóstico comum apontaram para a criação de uma rede densa de organizações e a multiplicação de lugares de confluência, que se situam em continuidade com um novo internacionalismo", assinala (ibid., p. 145). Esses espaços de confluência se articulam, a seu ver, em uma dinâmica multiescalonada que abarca o local, o nacional e o subcontinental. Estão em jogo, aqui, diferentes lógicas de territorialidade, em que se entrecruzam princípios de ação e racionalidades regidas por valores diferentes e, quase sempre, antagônicos.

De um lado, as lógicas territoriais das corporações e elites econômicas pautam-se pelo paradigma economicista, cuja finalidade maior é transformar os espaços em que se situam os recursos naturais considerados estratégicos em territórios eficientes e produtivos. De outro, a lógica territorial das populações locais, que se articulam em defesa de seu território, experenciado como comunidade de vida e patrimônio natural, social e cultural inalienável, que precisa ser mantido a salvo da ganância do mercado e de lógicas que lhes 
são estranhas. A análise dos conflitos socioambientais oferece uma chave de compreensão privilegiada, de acordo com Svampa (ibid.), de duas questões centrais da época contemporânea, o desenvolvimento e o meio ambiente, tão imbricadas quanto complexas. Tal abordagem integra a perspectiva da ecologia política, corrente de pensamento que faz a crítica à maximização do lucro e à mercantilização da natureza, entendendo que as relações entre os seres humanos e entre eles e a natureza constroem-se por meio de relações de poder (Castro, 2015, p. 238).

Em consonância com essa visão, Acselrad (2002) ressalta que a ação coletiva que se insurge contra a ordem ambiental dominante se manifesta em dois planos, complementares e indissociáveis entre si. Em primeiro lugar, no plano da distribuição objetiva dos efeitos ambientais das práticas sociais, em que se exprime a diferença de poder sobre os recursos ambientais dos distintos grupos sociais. Em segundo lugar, as disputas dão-se no plano discursivo, em que distintos esquemas de representação do mundo são confrontados e em que está em jogo a legitimidade do padrão de distribuição do poder sobre os recursos naturais.

É possível identificar a combinação desses dois planos no movimento Fórum Permanente Fora Lixão, criado em 2015, quando foi ativado o Lixão de Marituba por um consórcio privado. 0 movimento desdobrou-se em muitas ações e mobilizações, como o fechamento da BR316, que alcançaram grande repercussão na mídia local, além de ter se articulado com representantes da Assembleia Legislativa do Estado e da Câmara Federal, esferas em que a luta também teve muitas reverberações.

Acselrad (ibid.) destaca três posições centrais em torno da questão ambiental contemporânea. A primeira e dominante é a da modernização ecológica, pela qual instituições políticas incorporam a preocupação ecológica, movidas, no entanto, pelo propósito de conciliá-la com o crescimento econômico. Essa visão celebra a técnica e a economia de mercado e aposta na colaboração e no consenso.

A segunda posição é representada pela teoria da sociedade de risco, de Beck (1992), que aparentemente traria uma alternativa crítica radical. Essa teoria reconhece a existência do conflito ecológico e da desigualdade de poder sobre as técnicas e justifica a ação crítica do ecologismo. Na visão de Beck, a sociedade de risco teria surgido com a ascensão das sociedades industriais do século XIX. Nessa perspectiva, a crise ecológica contemporânea seria fruto do fracasso das instituições responsáveis pelo controle e pela segurança, que não conseguiram fazer frente aos riscos e acabaram por sancionar, na prática, a sua normalização legal.

Essa crítica, no entanto, dirige-se à racionalidade técnico-científica e não ao poder instituído do capital, razão pela qual Acserald a contesta. "[...] Nem os defensores da modernização ecológica nem os teóricos da sociedade de risco [...] incorporam analiticamente a diversidade social na construção do risco e a presença de uma lógica política a orientar a distribuição desigual dos danos ambientais" (Acserald, 2002, p. 51).

A terceira posição é a que estabelece uma relação direta entre degradação ambiental e injustiça social. Os sujeitos sociais partidários dessa posição não confiam no mercado como instrumento de superação da desigualdade ambiental e da promoção de princípios do que entendem por justiça ambiental. Nas palavras do autor: 
Estes atores consideram que há clara desigualdade social na exposição aos riscos ambientais, decorrente de uma lógica que extrapola a simples racionalidade abstrata das tecnologias. Para eles, o enfrentamento da degradação do meio ambiente é o momento da obtenção de ganhos de democratização e não apenas de ganhos de eficiência e ampliação de mercado. (Ibid.)

Conforme essa visão, portanto, as condições de acesso à proteção ambiental são socialmente desiguais e, mais que isso, inseparáveis das opressões de classe, raça e gênero. Os movimentos que se assentam nesses pressupostos e lutam pela justiça ambiental foram responsáveis, conforme Acserald, por trazer à tona uma agenda que estava submersa e invisível nas pautas políticas nacionais. Foi ainda nos anos 1960, nos Estados Unidos, que o movimento se constituiu, aliando de forma criativa lutas de caráter social, territorial, ambiental e de direitos civis. 0 ano de 1982 foi um marco fundamental, a partir da luta desenvolvida em Afton, condado de Warren, Carolina do Norte. Desde então surgiram outros movimentos similares, atribuindo às desigualdades ambientais no plano local o caráter de pauta política central na luta pelos direitos civis. Outro avanço muito significativo nesse sentido ocorreu em 1987, com a constatação, em pesquisa realizada pela Comissão de Justiça Racial da United Church of Christ, de que a composição racial de uma comunidade é uma variável determinante para explicar a existência ou a ausência de depósitos de rejeitos perigosos em uma determinada área. Cunhou-se, então, a expressão racismo ambiental (Pinderhughes, 1996) para referir-se à imposição de rejeitos perigosos às comunidades negras.
O movimento contra a desigualdade ambiental nos EUA construiu a base da resistência global que se articulou contra a desigual distribuição dos danos ambientais, evidenciando que há uma divisão social do ambiente, em que as classes pobres e negras, por serem dotadas de pouca mobilidade social, são espacialmente segregadas, com a transferência de atividades predatórias ao meio ambiente para seus locais de moradia (Acserald, 2002, p. 57).

Pode-se dizer que a compreensão de tais assimetrias socioambientais passa pelo entendimento fanoniano de racismo. Para Fanon (2008), o racismo é uma hierarquia global de superioridade e inferioridade sobre o que ele denomina "linha do humano", que, desde o século XVI, tem sido politicamente reproduzida como estrutura de dominação. Conforme explica Grosfoguel (2012), autor caribenho, as pessoas que estão acima da linha do humano são reconhecidas socialmente em sua humanidade e como sujeitos de direitos, humanos, sociais, trabalhistas e, acrescentam-se, ambientais. Pessoas abaixo dessa linha são consideradas sub-humanas ou não humanas, portanto, sua humanidade é negada.

Inspirado em Fanon, Souza Santos (2019, p. 43) define como "linha abissal" a divisão que revela os dois mundos de dominação criados a partir do colonialismo histórico. De um lado, o mundo metropolitano, "da equivalência e da reciprocidade entre 'nós', os 'integralmente humanos', com sociabilidades regidas pelas tensões entre regulação social e emancipação e ao alcance de seus mecanismos" - 0 Estado liberal, o Estado de direito, os direitos humanos, a democracia. E, de outro lado, o mundo colonial, o mundo do "eles", aqueles que estão do outro lado da linha abissal, na qual as formas de sociabilidade são geridas 
por dinâmicas de apropriação e violência, das vidas e dos recursos, ou seja, por regulações violentas - o Estado colonial e neocolonial, o apartheid, o trabalho forçado e o trabalho escravo, a tortura, a apropriação primitiva do capital, o racismo, o feminicídio, entre outras tantas violências estruturais, assim como o ecocídio e o epistemicídio.

Também sob inspiração de Fanon, Quijano (2005) desenvolve o conceito de colonialidade do poder como matriz cultural de classificação social que, mesmo findo o colonialismo histórico, naturaliza-se de forma cotidiana no próprio processo de reprodução e manutenção de um determinado padrão de poder. Um padrão pioneiro de poder mundial, forjado a partir da constituição do "Novo Mundo", no entrecruzamento de dois fatores centrais que, segundo o autor, erguem e sustentam até hoje o sistema-mundo moderno colonial capitalista (Wallerstein, 1999) - a classificação da população mundial a partir da ideia de raça e a articulação de todas as formas de controle do trabalho. Para Quijano (2005 e 2009), como explicam Porto-Gonçalves e Quental (2012), as identidades sociais inventadas pela classificação racial da população mundial associam-se aos poucos ao lugar que esses grupos passam a ocupar na divisão do trabalho no sistema capitalista então emergente. Aos índios, servidão; aos negros, escravidão; ao europeu, trabalho assalariado.

Neste mesmo processo, os territórios e organizações políticas de base territorial foram sendo classificados de acordo com a suposta posição "racial" em que seus habitantes eram situados. [...] A partir da ideia de raça, portanto, se institui um conjunto de relações de poder que hierarquizam os lugares e suas gentes. (Porto-Gonçalves e Quental, 2012, p. 42)
O Lixão de Marituba aqui analisado, situado no município com piores índices de desenvolvimento humano (IDH) da Região Metropolitana de Belém, onde a vulnerabilidade social em todas suas dimensões - não como exceção - se agudiza quando cruzada com a variável "cor" de seus habitantes, constitui caso exemplar a ilustrar uma segregação com marcas neocoloniais que se reflete numa injusta ordem ambiental, com a permanente exposição da saúde da população de seu entorno a toda sorte de riscos, contaminações e a um desconforto reiterado a cada dia. Neste último, há que se considerar a dimensão subjetiva do mal-estar, do sentir-se parte do lixo, do péssimo odor que impregna tudo e todos ao redor. Como atestam, de maneira contundente, narrativas de moradores no entorno do Lixão:

Eu me senti invadida. Parecia que tiraram uma parte da gente, tiraram o que era nosso, entraram e arrebataram. Disseram vai ser aqui e pronto. Não pediram permissão, não teve votação e agora pra tirar tem que passar por cima de muita coisa. E não tiram, não querem nos escutar. (Moradora 1. Entrevista concedida em 28/3/2018) $)^{20}$

O Lixão começou a ser construído há cinco, seis anos atrás. Perto de onde morei [...] minha infância foi dentro dela, área de reserva, nativa, muito bonita. Depois desmataram, transformaram num "curvão", a área que hoje é o lixão, e virou um buraco de cinco metros de profundidade, gigantesco buraco, depois foram colocando lixo, lixo e hoje já temos cinquenta metros de altura só de lixo. Vimos todo esse processo acontecer. (Morador 1. Entrevista concedida em 28/3/2018) 
Mudou tudo. Fez afastar o movimento, aqui no centro a cidade parece um cemitério. [...] O fedor vem bater aqui na praça, às vezes ele atravessa a cidade. (Trabalhador autônomo, vendedor de lanches. Entrevista concedida em $28 / 3 / 2018)$

Trazida à agenda pública, a justiça ambiental passou a ocupar a centralidade da pauta de grande parte das lutas sociais em curso no mundo contemporâneo, com ênfase especial às que se desenrolam nos países latinoamericanos, onde se constituíram várias redes em torno dessa luta. Nesse processo estão em pauta a desigualdade dos custos ambientais, a ausência de participação e de mecanismos democráticos, o racismo ambiental, a injustiça de gênero e a dívida ecológica (Svampa, 2016).

No entanto, a que se refere precisa e conceitualmente a justiça ambiental? De acordo com Acserald (2004, p. 16), ela "implica o direito a um ambiente seguro, sadio e produtivo para todos, o meio ambiente sendo considerado em sua totalidade, incluindo as dimensões ecológicas, físicas, construídas, sociais, políticas estéticas e econômicas". Esse direito, conforme o autor, deve ser exercido livremente, de maneira a respeitar as identidades individuais e de grupo e a dignidade e autonomia das comunidades.

O conceito de justiça ambiental equivale-se ao de Bem Viver, uma ideia em construção, segundo Acosta (2016, p. 33), que "pode servir de plataforma para discutir, consensualizar e aplicar respostas aos devastadores efeitos das mudanças climáticas e às crescentes marginalizações e violências sociais". O Bem Viver surge de visões utópicas, formulado como uma proposta de luta contra a colonialidade do poder, coloca em xeque o conceito eurocêntrico de bem-estar, que se assenta na premissa da acumulação perpétua e em padrões de consumo insustentáveis.

"Produção e consumo se tornam, assim, uma espiral interminável, esgotando os recursos naturais de maneira irracional e acirrando ainda mais a tensão criada pelas desigualdades sociais" (ibid., p. 36) Inspira-se, em grande medida, no modo de vida indígena. No entanto, o autor ressalta que vai além de visões andinas e amazônicas, buscando contemplar diversas vozes que se erguem no mundo, inclusive em círculos da cultura ocidental, como os ecologistas, as feministas, os cooperativistas, os marxistas, os humanistas, entre outros (ibid.., p. 34).

No próximo tópico, discutiremos narrativas dos moradores do Lixão de Marituba à luz das contribuições de Foucault (1999) e Mbembe (2016 e 2018), que complementam as discussões feitas neste tópico.

\section{Racismo de estado e necropolítica: viver e morrer no lixo}

No curso "Em defesa da sociedade", Foucault (1999) ocupa-se em discutir os operadores da dominação naquilo que têm de efetivos, factuais e empiricamente verificáveis ao longo da história. Ao fazê-lo, quer ir além do que denomina "tríplice primitivismo" em que se ancora a soberania do poder - do sujeito que deve ser sujeitado, da unidade do poder que deve ser fundamentada e da legitimidade que deve ser respeitada. ${ }^{21}$ Ao fazer esse deslocamento, Foucault introduz a noção de racismo 
de Estado, fundamental para a discussão feita aqui do objeto sobre o qual nos debruçamos neste artigo.

Para Foucault, há um discurso de guerra perpétua que atravessa a história do mundo ocidental. "Vê-se a ideia segundo a qual a guerra constitui a trama ininterrupta da história [...] a guerra que se desenrola assim sob a guerra e sob a paz, a guerra que solapa a nossa sociedade e a divide de modo binário é, no fundo, a guerra das raças" (ibid., p. 70). 0 autor reconhece, a partir dessa constatação, que a raça é uma espécie de "entroncamento essencial" para analisar as dinâmicas do poder na sociedade e que o corpo social, no fundo, é articulado a partir de duas raças.

Trata-se de um racismo biológico-racial, que se infiltra e se recria permanentemente no corpo social. Conforme a visão foucaultiana, essa fratura binária, que se expressa naquilo que percebemos como polaridade, "não é o enfrentamento de duas raças exteriores uma à outra; é o desdobramento de uma única e mesma raça em uma superraça e uma subraça [...] Em resumo, o avesso e a parte de baixo da raça que aparece nela" (ibid., p. 72).

Dessa maneira, o discurso da luta das raças que emergiu no século XVII acabou por se converter no próprio discurso do poder, que se assenta no embate travado não entre duas raças, mas a partir daquela que se impõe como sendo a única e verdadeira raça, aquela que detém o poder e é titular da norma. É ela que dita quem está dentro e quem está fora da norma e investe contra aqueles que representam supostamente vários perigos para o patrimônio biológico. Os discursos biológico-racistas sobre degenerescência, nesse momento, funcionaram como matriz discursiva que passou a reger o funcionamento das instituições do corpo social. Desde então, foi tomado como princípio de eliminação, de segregação e, finalmente, de normalização da sociedade.

"Temos de defender a sociedade contra todos os perigos biológicos dessa outra raça, dessa subraça, dessa contrarraça que estamos, sem querer, constituindo" (ibid., p. 73), sentencia o filósofo sobre o princípio que passa a reger a sociedade e vai servir à estratégia global dos conservadorismos sociais. 0 racismo de Estado, assim configurado, passará a ser um dos pilares da normalização social. 0 Estado moderno assenta-se na correlação intrínseca entre racismo, mecanismos do Estado e biopoder.

O biopoder refere-se, como o termo sugere, ao poder exercido sobre a vida, mas não sobre o corpo individual, e sim sobre a vida da população, em que se dá uma espécie de estatização do biológico. Uma nova tecnologia do poder passa a vigorar, gerindo a vida da população, contabilizada em números e estatísticas, segundo critérios demográficos. Natalidade, mortalidade, longevidade, controle de epidemias e endemias, securidade, tudo está no âmbito da biopolítica e do biopoder. Foucault acredita ter havido uma maciça transformação no século XIX.

Um dos pontos-chave da mudança ocorrida, na visão foucaultiana, é a inversão do direito de vida e morte que o soberano detinha na teoria clássica da soberania, assentado na premissa de poder fazer morrer e deixar viver. Na nova configuração do poder, a premissa é deixar morrer para fazer viver, o que caracteriza precisamente o racismo de Estado, em que se evidencia o que Foucault (ibid.) chama de "a função assassina do Estado". Em outras palavras, decide-se quem precisa morrer para que outros possam viver. E não se trata somente da 
morte física, mas também da simbólica, muito importante no objeto em discussão aqui. Morrer simbolicamente pode significar estar condenado à expulsão, à rejeição, à degradação, à retirada de direitos. Nada mais apropriado para compreender o jogo de vida e morte implicado no Lixão de Marituba e em tantos outros lixões urbanos. Uma espécie de morte em vida.

Vocês não sabem o que é conviver com o fedor, dormir com o fedor [...] Hoje não temos mais caça, perdemos nosso igarapé, que era as férias de nossos filhos. (Representante da comunidade quilombola do Abacatal)

Mbembe (2011) radicalizou a concepção de biopoder de Foucault, por considerá-la insuficiente, "para refletir as formas contemporâneas de submissão da vida ao poder da morte" 22 (p. 75). Formula, assim, os conceitos de necropoder e de necropolítica, para apontar novas formas de dominação e de submissão, em particular tendo como ponto de partida a África pós-colonial. No mundo pós-colonial o poder é difuso, a seu ver, não necessariamente exercido pelo Estado. A economia da morte inscreve-se nas relações de produção e de poder. A expressão última da soberania reside amplamente, conforme Mbembe (2016), no poder de dizer quem pode viver e quem deve morrer. Tanto quanto Foucault, ele localiza na raça a raiz das formas de dominação que imperaram desde a colonização europeia na América.

No decorrer dos séculos, Mbembe assinala que a raça funcionou como categoria originária, material e fantasmática, que esteve "na origem de inúmeras catástrofes, tendo sido a causa de devastações psíquicas assombrosas e de incalculáveis crimes e massacres" (2018, p. 13). 0 que se experimenta hoje no mundo pós-colonial é o ocaso europeu e o que chama de um "imperialismo da desorganização", que fabrica desastres e dissemina por toda parte as condições de exceção, fazendo prosperar em muitos países um "racismo sem raças", responsável por exercer com mais desenvoltura a discriminação. A raça não deixou de ser um marcador determinante da diferença e da desigualdade, mas o racismo serviu de pretexto para discriminações de toda ordem, difusas, reiteradas e violentas, que investem contra os corpos negros, contra os corpos pobres das periferias. Por essa razão é que ele antevê um devir-negro do mundo.

Essa é a cena e drama cotidiano entre os moradores afavelados de Marituba, onde viver no meio do lixo e de seu odor insuportável é um modo a mais de morrer lentamente, de submeter-se ao necropoder. Os depoimentos a seguir falam por si sós a esse respeito.

O fedor está com essa faixa de dois anos, mas em novembro do ano passado eu comecei com falta de ar e uma canseira e em dezembro vieram muito fortes as dores, dor no peito. Quando o odor está muito forte eu ia pra frente do ventilador, mas aquilo vai sufocando, vai sufocando... quando passa o fedor forte aquilo melhora. (Moradora 2. Entrevista concedida em 28/3/2018)

Muita gente apresentou problema de úlcera que não tinha. No momento em que eu fiquei mais em casa, eu também comecei a sentir. Boca áspera, lábios secos, língua travosa. Como sempre estivesse comendo uma fruta verde [...] A gente dorme, acorda, no café da manhã, não tem hora... ninguém convida mais 
ninguém (pra vir em casa) porque é insuportável. (Moradora 1. Entrevista concedida em 28/3/2018, já citada)

\section{Considerações finais}

Pretendeu-se, neste artigo, trazer ao debate as noções de injustiça ou racismo ambiental, questão de fundo e chave para compreender a lógica imemorial dos conflitos socioambientais, considerando, para isso, diferentes narrativas em disputa. Tal discussão se ancorou, empiricamente, na desigual distribuição dos danos ambientais relativos à destinação do lixo na Região Metropolitana de Belém, principal metrópole de uma invisibilizada Amazônia urbana.

A prática de se alocarem instalações de esgoto e lixo em áreas habitadas por trabalhadores pobres, desprovidos e pertencentes a populações negras e de minorias étnicas não é recente, tendo sido observada desde a Antiguidade, como assinala Acserald (2002, p. 52). Os rejeitados, os deportados, os clandestinos, os "semdocumentos" são denominados, por Mbembe (2018, p. 306), "os intrusos" e a "escória da humanidade" - vítimas de históricas "exclusões pós-abissais", nos termos de Boaventura Santos, situados para além da "linha do humano", conforme Fanon.

Evidencia-se, assim, a reafirmação de uma estratégia de dominação pela sujeição, do controle pela desclassificação do outro, tornado "coisa", descartável, passível de ser destinado a lugares "inadmissíveis" ao desenvolvimento do humano, como a cena crescente de populações mais pobres e vulneráveis nos chamados aglomerados subnormais das periferias metropolitanas, como a do Lixão de Marituba.

A racialização das estruturas de poder colonial (Quijano, 2005) reaparece atualizada nas disputas ambientais contemporâneas. Revela-se objetivamente, como diz Acserald (2002), nos efeitos diretos de uma injusta e desigual distribuição ecológica, no acesso aos bens e recursos, ao bem-estar e ao bem viver de indivíduos e grupos sociais. Transparece, subjetivamente, nos embates das gramáticas discursivas, na sordidez do poder dissimulador de suas responsabilidades, na insensibilidade e prepotência das burocracias e, muitas vezes também, na sedução dos discursos falsos e fáceis do pensar mercantil.

Porém, nem tudo são sombras. 0 projeto de um mundo comum, em que possam vigorar os princípios da igualdade e da unidade fundamental do gênero humano, é universal, como projeta Mbembe (2018), e talvez já seja possível detectar no presente alguns frágeis sinais nessa direção. Eles surgem na resistência, no ato de agir e persistir. Nas lutas coletivas que se reinventam ao transbordar e sensibilizar para além da rigidez de um pensamento único ou de uma noção de classe. Nenhum avanço nesse sentido, porém, poderá ser substancial enquanto persistirem o racismo e a autodecretada superioridade de uma raça em relação à outra.

Aqueles a quem o pensador africano, em referência ao filósofo e revolucionário caribenho, ${ }^{23}$ chama de "os novos condenados da Terra" é negado o direito de ter direitos, bem como o direito de se moverem. Assim, estão condenados a viver em todo tipo de 
estruturas de reclusão e exclusão - os campos, os centros de triagem, os milhares de locais de detenção - às quais poderíamos acrescentar as periferias pobres, desassistidas e violentas das grandes cidades, onde, em geral, situam-se, quando ainda perduram, como no Norte e Nordeste do País, as áreas dos lixões urbanos ou aterros irregulares, como o de Marituba, na Região Metropolitana de Belém do Pará.

\section{[I] https://orcid.org/0000-0003-4321-7245}

Universidade Federal do Pará, Faculdade de Comunicação, Programa de Pós-Graduação de Comunicação, Cultura e Amazônia. Belém, PA/Brasil.

steinbrenner@ufpa.br

\section{[II] https://orcid.org/0000-0001-7102-0293}

Universidade Federal do Pará, Faculdade de Comunicação, Programa de Pós-Graduação de Comunicação, Cultura e Amazônia. Belém, PA/Brasil.

rosalysbrito@gmail.com

\section{[III] https://orcid.org/0000-0001-9297-4168}

Universidade Federal do Pará, Núcleo de Altos Estudos Amazônicos, Programa de Pós-Graduação em Desenvolvimento Sustentável do Trópico Úmido, . Belém, PA/Brasil.

edna.mrcastro@gmail.com

\section{Notas}

(1) A noção de obsolescência programada embala a lógica atual do sistema capitalista que se autorreproduz no descarte cada vez mais antecipado de mercadorias que velozmente perdem o sentido de utilidade (Mèzsarós, 2002, apud Zanetti, Mourão Sá e Almeida, 2009).

(2) Resíduo sólido é todo "material, substância, objeto ou bem descartado resultante de atividades humanas em sociedade, cujas particularidades tornem inviável o seu lançamento na rede pública de esgotos ou em corpos d'água (Brasil, 2010, cap. 2, item XVI).

(3) 36 países são membros da OCDE - Organização para a Cooperação e o Desenvolvimento Econômico, criada após a Segunda Grande Guerra. Nas últimas décadas, desde 1980, esses países, com elevado PIB per capita, aumentaram em $35 \%$ o índice per capita de geração de lixo (World Bank, 2012).

(4) Resíduos Sólidos Urbanos (RSU) - resíduos domiciliares e de limpeza urbana (varrição, limpeza de logradouros e vias públicas e outros serviços de limpeza urbana) (Brasil, 2012).

(5) RMB: Belém, Ananindeua, Marituba, Benevides, Santa Isabel do Pará, Santa Bárbara do Pará (e mais recente, anexado em 2011, o município de Castanhal). 
(6) O Instituto Evandro Chagas (IEC), órgão vinculado ao Ministério da Saúde (MS), é considerado referência mundial como centro de excelência em pesquisas científica e investigação.

(7) Secretaria da Vara Criminal de Marituba (Jusbrasil, 2017).

(8) Ver site <http://www.solvi.com/> e publicação corporativa do grupo http://docs.wixstatic.com/ ugd/499343_43ddf5292e8f44dda9010c404b3a1d05.pdf.

(9) Decreto da prefeitura municipal de Marituba, de 20 de março de 2017, publicado no DOM no dia 31 de março. Disponível em Prefeitura de Marituba (2017).

(10) Resíduo líquido poluente e de odor nauseante, formado a partir da decomposição de matéria orgânica presente no lixo (Wikipédia).

(11) Ver: https://www.facebook.com/foralixaomarituba/ e https://foralixaomarituba.wixsite.com/forali xaomarituba?fbclid=IwAR2DxeSc_I_iocRP-zFo4pnn5Ixw1UEZDu 95CsMy96BsyhqAJGrlGdwXQr8.

(12) População estimada pelo IBGE 2018 e PIB per capita, disponível em: Fórum Nacional de Entidades Metropolitanas - FNEM (2017 e 2018).

(13) Como efeito dos vários projetos de ocupação da Amazônia, a região registrou as maiores taxas de crescimento urbano no País, com uma população que aumentou de 35\% em 1970 para $72 \%$ em 2007 (Becker, 2013).

(14) O setor terciário da economia, de serviços, responde por $83 \%$ do PIB da Região Metropolitana de Belém, sendo mais acentuado, ainda, na capital, $85 \%$ do PIB de Belém, seguido por Marituba, $80 \%$ do PIB municipal, $79 \%$ de Ananindeua e $78 \%$ do PIB de Castanhal.

(15) Segundo definição utilizada pelo IBGE (2010), aglomerações subnormais (AS) são identificadas a partir de um conjunto constituído de, no mínimo, 51 unidades habitacionais (barracos, casas, etc.) carentes, em sua maioria, de serviços públicos essenciais e estando dispostas, em geral, de forma desordenada e densa.

(16) O Índice de Vulnerabilidade Social (IVS) considera 16 indicadores reunidos em três dimensões infraestrutura urbana, capital humano, trabalho e renda -, a partir da desagregação dos dados do Censo e da Pesquisa por Amostragem de domicílios (PNAD), realizados pelo IBGE. O índice é resultado da média aritmética dos subíndices e varia de 0 a 1 , de uma vulnerabilidade social muito baixa $(0$ a 0,2$)$, baixa $(0,2$ a 0,3$)$, média $(0,3$ a 0,4$)$, alta $(0,4$ a 0,5$)$ e muito alta $(0,5$ a 1$)$. Ver: http://ivs.ipea.gov.br.

(17) O Índice de Desenvolvimento Humano Municipal (IDHM) adapta, aos municípios, a metodologia desenvolvida para mensurar o desenvolvimento humano de países. Trata-se de uma medida composta de indicadores de três dimensões do desenvolvimento humano: longevidade, educação e renda. $O$ índice varia de 0 a 1 . Quanto mais próximo de 1 , maior o desenvolvimento humano (Atlas do Desenvolvimento Humano, s/d).

(18) Ver matéria Portal UFPA (2017).

(19) Entrevista concedida em 28/3/2018, após Audiência Pública da Câmara Federal, realizada no Salão Paroquial Menino Jesus, em Marituba, por iniciativa do deputado federal Edmilson Rodrigues (PSOL).

(20) Ao citarmos a fala dos moradores da área do entorno do Lixão de Marituba, faremos uso de uma ordem sequencial que os identifica, distinguindo apenas o gênero dos entrevistados. 
(21) Quer assuma a fisionomia do monarca ou a forma do Estado, para Foucault (1999) a soberania apoia-se na unidade do poder. "A multiplicidade dos poderes só pode ser estabelecida e só pode funcionar a partir da unidade do poder, fundamentada pela teoria da soberania" (p. 51). Segundo ele, a soberania é o ciclo do sujeito para o sujeito e não se funda exatamente na lei, e sim em uma legitimidade fundamental, que transcende a lei e é mais fundamental do que todas as leis.

(22) Tradução nossa do original: “[...] Para reflejar las formas contemporáneas de sumisión de la vida al poder de la muerte" (Mbembe, 2016, p. 75).

(23) Última obra de Franz Fanon (Fanon, 1961), trata dos efeitos devastadores da colonização sobre os povos do Sul global, também sobre o contexto das lutas pela Independência e libertação da Argélia.

\section{Referências}

ACOSTA, A. (2016). O bem viver: uma oportunidade para imaginar outros mundos. Editora Elefante Autonomia Literária. Disponível em: https://rosaluxspba.org/wpcontent/uploads/2017/06/ Bemviver.pdf. Acesso em: 23 abr 2018.

ACSERALD, H. (2002). Justiça ambiental e a construção social do risco. Desenvolvimento e Meio Ambiente, n. 5, pp. 49-60. Curitiba, Editora UFPR.

(org.) (2004). Conflitos ambientais no Brasil. Rio de Janeiro, Relume Dumará/Fundação Heinrich Böll.

ACSERAlD, H.; MELLO, C. C. do A.; BeZERRA, G. das N. (2009). O que é Justiça Ambiental. Rio de Janeiro, Garamond.

ALVAREZ, R. A. (2014). Retrato dos resíduso sólidos no Brasil. Revista Em Discussão. Senado Federal, ano 5, n. 22, pp. 16-18. Disponível em: http://www.senado.gov.br/noticias/jornal/emdiscussao/ residuos-solidos/residuos-solidos.pdf. Acesso em: 18 set 2018.

ATLAS DO DESENVOLVIMENTO HUMANO (s/d). IDHM. Disponível em: http://www.atlasbrasil.org. br/2013/pt/o_atlas/idhm/ Acessado em: 27 set 2019.

BAHIA, V. E.; LEAL, R. B. (2018). Características hidrogeológicas da área do aterro sanitário de Marituba (PA). In: XX CONGRESSO BRASILEIRO DE ÁREAS SUBTERRÂNEAS. Anais... 6 a 8 de novembro, Campinas. SP. Disponível em: <http://www.abas.org/xxcabas/anais/10381.pdf>. Acesso em: 12 jan 2019.

BECK, U. (1992). Risk Society: towards a new modernity. Califórnia, Sage Publications.

BECKER, B. (2013). A urbe amazônida: a floresta e a cidade. Rio de Janeiro, Garamond.

BRASIL (2010). Política Nacional de Resíduos Sólidos. Lei n. 12.305, de 2 de agosto de 2010. Publicação DOU, de 3/8/2010. Disponível em: <http://fld.com.br/catadores/pdf/politica_residuos_solidos. pdf> Acesso em: 15 out 2018. 
BRASIL (2012). Plano Nacional de Resíduos Sólidos. Disponível em:< https://sinir.gov.br/images/sinir/ Arquivos_diversos_do_portal/PNRS_Revisao_Decreto_280812.pdf>. Acesso em: 16 out 2018.

BRASIL. Diagnóstico do manejo de Resíduos Sólidos Urbanos (2017). Sistema Nacional de Informação sobre Saneamento (SNIS). Ministério do Desenvolvimento Regional, Brasília. Disponível em: <http://www.snis.gov.br/diagnostico-anual-residuos-solidos/diagnostico-rs-2017>. Acesso em: $19 \operatorname{mar} 2019$.

BRASIL. MINISTÉRIO DO DESENVOLVIMENTO REGIONAL (2019). Diagnóstico do manejo de Resíduos Sólidos Urbanos, 2017. Sistema Nacional de Informação sobre Saneamento (SNIS). Ministério do Desenvolvimento Regional, Brasília.

CASTRO, E. (2006). "Prefácio". In: CARDOSO, A. C. D. (org.). O rural e o urbano na Amazônia. Diferentes olhares em perspectivas. Belém, EDUFPA.

(2015). "Campo do desenvolvimento, racionalidade, ciência e poder". In: FERNANDES, A. C.; LACERDA, N.; PONTUAL, V. Desenvolvimento, planejamento e governança: expressões do debate contemporâneo. Rio de Janeiro, Letra Capital/Anpur.

CASTRO, E.; FREITAS PINTO, R. E. (orgs.) (2018). Decolonialidade \& Sociologia na América Latina. Belém, Ed. NAEA, UFPA.

COLOMBIJN, F.; RIAL, C. (2016). “Abordagens antropológicas dos resíduos sólidos em sociedades pós-industriais”. In: RIAL, C. (org.). O poder do lixo; abordagens antropológicas dos resíduos sólidos. Rio de Janeiro, Associação Brasileira de Antropologia.

DARDOT, P.; LAVAL, C. (2016). A nova razão do mundo: ensaio sobre a sociedade neoliberal. São Paulo, Boitempo.

DIÁRIO OFICIAL do Município de Belém (2015). Extrato do Contrato Administrativo n. 09/2015SESAN/ PMB. Dispensa de Licitação n. 02/2015SESAN.DOMB, Ano LVI n. 12.832, p. 7, 22 jun.

DOUGLAS, M. (1966). Pureza e perigo: ensaios sobre sujeira e tabu. Lisboa, Ed. 70.

ESCOBAR, A. (2005). Más allá del Tercer Mundo: globalización y diferencia. Bogotá, Instituto Colombiano de Antropología e Historia/Universidad del Cauca. Disponível em: <http://www. unc.edu/ aescobar/text/esp/mas\%20alla\%20del\%20tercer\%20mundoimpreso.pdf > Acesso em: 21 maio 2018.

FANON, F. (2008). Pele negra, máscaras brancas. Salvador, EDUFBA.

(2016). Les damnés de la terre. Flórida, Hope Outreach Productions.

FNEM - Fórum Nacional de Entes Metropolitanos. (2017). Estimativa populacional. Disponível em: http://fnembrasil.org/wpcontent/uploads/2018/06/pib_UR.jpg. Acesso em: 15 dez 2018.

(2018). PIB 2015. Produto Interno Bruto. Regiões Metropolitanas por município. Disponível em: <http://fnembrasil.org/wp content/uploads/2018/06/pib_UR.jpg>. Acesso em: 15 dez 2018.

FOUCAULT, M. (1999). Em defesa da sociedade. São Paulo, Martins Fontes.

(2008). Nascimento da biopolítica. São Paulo, Martins Fontes.

GROSFOGUEL, R. (2012). El concepto de «racismo» en Michel Foucault y Frantz Fanon: ¿̇eorizar desde la zona del ser o desde la zona del no-ser? Tabula Rasa. Bogotá, Colômbia, n. 16, pp. 79-102.

HARVEY. D. (1980). A justiça social e a cidade. São Paulo, Hucitec. 
HOORNWEG, D.; BHADATATA, P. (2012). What a waste: a global review of solid waste management. Urban development series knowledge papers, n. 15. World Bank, Washington, DC. C World Bank. Disponível em: <https://openknowledge.worldbank.org/handle/10986/17388> Acesso em: 12 fev 2018.

IBGE - Instituto Brasileiro de Geografia e Estatística (2003). IBGE Cidades@. Marituba. Disponível em:<https://cidades.ibge.gov.br/brasil/pa/marituba/panorama>. Acesso em: 10 jun 2019.

(2010). Censo 2010. Disponível em: https://censo2010.ibge.gov.br/>. Acesso em: 25 jan 2019.

(2018). Estimativas de População. Disponível em: <https://www.ibge.gov.br/estatisticas/ sociais/populacao/9103-estimativas-de-populacao.html ?edicao=22367\&t=resultados>. Acesso em: 30 set 2019.

IPEA - Instituto de Pesquisa Econômica Aplicada (2010). Atlas de vulnerabilidade social dos municípios e regiões metropolitanas brasileiras. Disponível em:<http://ivs.ipea.gov.br/index.php/pt/ planilha>. Acesso em: 10 jun 2019.

(2015). Relatório de Pesquisa Caracterização e Quadros de Análise Comparativa da Governança Metropolitana no Brasil: arranjos institucionais de gestão metropolitana (Componente 1) Região Metropolitana de Belém. Rio de Janeiro, Ipea.

JUSBRASIL (2017). Referência ao processo (MP): 0009250-89.2017.8.14.0133. Disponível em: https:// www.jusbrasil.com.br/diarios/documentos/535913883/andamento-do-processo-n-00092508920178140133-11-de-dezembro-do-tjpa?ref=topic-lawsuit.

MARTINS, J. de S. (2009). Fronteira: a degradação do outro nos confins do humano. São Paulo, Contexto.

MATOS, F. O. et al. (2011). Impactos ambientais decorrentes do aterro sanitário da região metropolitana de Belém - PA: aplicação de ferramentas de melhora ambiental. Caminhos da Geografia. Uberlândia, v. 12, n. 39, pp. 297-305. Disponível em: <http://www.seer.ufu.br/index. php/caminhosdegeografia/article/view/16593>. Acesso em: 13 dez 2018.

MBEMBE, A. (2008). Por un entierro simbólico del colonialismo: imaginario y espacio público en África. Duala/Camerún, Le Messager.

(2011). Necropolítica seguido de Sobre el gobierno privado indirecto. Madri, Melusina.

(2016). Necropolítica. Arte \& Ensaios. Revista do PPGAV/EBA/UFRJ. n. 32, pp. 123151.

(2018). Crítica da razão negra. São Paulo, n1 edições.

MPPA - Ministério Público do Pará (2019). http://www.mppa.mp.br/noticias/conforme-exigencia-domp-aterro-de-marituba-sera-encerrado-em-no-maximo-dois-anos.htm.

(2020). Disponível em: <https://www2.mppa.mp.br/noticias/inquerito-civil-vai-apurarlicenciamento-ambiental-de-aterro-sanitario.htm>.

NADALIN, V. G.; KRAUSE, C.; LIMA NETO, V. C. (2014). Distribuição de aglomerados subnormais na rede urbana e nas grandes regiões brasileiras. Texto para discussão do IPEA n. 2012. Ipea - Instituto de Pesquisa Econômica Aplicada.

O LIBERAL(2019). ComunidadespróximasdoaterrodeMaritubaestãoexpostasacontaminantesmetálicos. Portal ORM. Disponível em: <https://www.oliberal.com/belem/exclusivo-nove-comunidadesde-marituba-est\%C3\%A3o-expostas-a-contaminantes-met\%C3\%A1licos-1.57874>. Acesso em: 5 fev 2019. 
ONU BR - Organização das Nações Unidas no Brasil (2015/2016). No Brasil, 80 mil toneladas de resíduos sólidos são descartadas de forma inadequada por dia. Publicado em 14/8/2015. Atualizado em 9/4/2016. Disponível em:<https://nacoesunidas.org/no-brasil-80-mil-toneladas-de-residuossolidos-sao-descartados-de-forma-inadequada-afirma-onu/>. Acesso em: 13 dez 2017.

PARÁ. SEMAS - Secretaria de Estado de Meio Ambiente e Sustentabilidade (2017). Notificação Guamá Tratamento de Resíduos Sólidos, de 22/3/2017. Disponível em: https://www.semas.pa.gov. br/2017/04/11/documentos/. Acesso em: 13 dez 2017.

PEREIRA, L. O. M. (2015). Impactos relacionados à implantação do Aterro Sanitário de Marituba. Comissão do Meio Ambiente e Desenvolvimento Sustentável. Câmara Federal.

PINDERHUGHES, R. (1996). The impact of race on environmental quality: an empirical and theoretical discussion. Sociological Perspectives, v. 39, n. 2, pp. 231-248.

POLANYI, K. (2000). A grande transformação. As origens da nossa época. Rio de janeiro, Compus. Disponível em: https://edisciplinas.usp.br/pluginfile.php/262942/mod_resource/content/2/A_grande_ transformac\%CC\%A7ao_as_origens_de_nossa_epoca_Polanyi.pdf. Acesso em: 22 ago 2017.

PORTAL G1 - Pará (2017a). Matéria de 6/12/2017. Disponível em: https://g1.globo.com/pa/para/ noticia/policia-civil-e-ministerio-publico-fazem-operacao-para-combater-crimes-ambientais-nopara.ghtml.

(2017b). Justiça nega habeas corpus a diretores das empresas que operam aterro de Marituba, publicado em 18/12/2017. Disponível em: https://g1.globo.com/pa/para/noticia/justica-negahabeas-corpus-a-diretores-das-empresas-que-operam-aterro-de-marituba.ghtml.

(2019). Disponível em: https://g1.globo.com/pa/para/noticia/2019/05/31/justica-determinaque-aterro-de-marituba-continue-a-funcionar.ghtml.

PORTO-GONÇALVES, C. W. (2012). A ecologia política na América Latina: reapropriação social da natureza e reinvenção dos territórios. INTERthesis. Revista Internacional Interdisciplinar. Ciências Humanas. PPGICH. UFSC. Florianópolis, v. 9, n. 1. Disponível em: https://periodicos.ufsc.br/index. php/interthesis/article/view/25431. Acesso em: 13 maio 2018.

PORTO-GONÇALVES, C. W.; QUENTAL, P. de A. (2012). Colonialidade do poder e os desafios da integração regional na América Latina. Polis [Online], n. 31. Disponível em: http://journals. openedition.org/polis/3749. Acesso em: 7 jan 2019.

PREFEITURA DE MARITUBA (2017). Decreto n. 508 de 20 de março de 2017. Disponível em: https:// www.marituba.pa.gov.br/site/decreto-no-508-de-20-de-marco-de-2017/. Acesso em: 13 dez 2017.

QUIJANO, A. (2005). Colonialidad y modernidad-racionalidad. Disponível em: <http://pt.scribd.com/ doc/36091067/Anibal-Quijano-Colonialidade-e-Modernidade-Racionalidade>. Acesso em: 16 jun 2017.

(2009). “Colonialidade do poder e classificação social”. In: SANTOS, B. de S.; MENEZES, M. P. (orgs.). Epistemologias do Sul. Coimbra/Portugal, Almedina.

SIROTHEAU, J. L. T. (2019). “Impactos socioterritoriais em quilombos na Região Metropolitana de Belém (RMB). O caso da comunidade de Abacatal, em Ananindeua". In: TRINDADE JUNIOR, S. C. da; VELOSO DOS SANTOS, T. (orgs.). O urbano e o metropolitano em Belém. Rio de Janeiro, Consequência. 
SOLVI PARTICIPAÇÕES (s/d). Demonstrativo de movimentações financeiras, individuais e consolidadas em 31 de dezembro de 2017 e 2016. Disponível em: <http://docs.wixstatic.com/ugd/499343_7c c85e66489c48e3bcc6e00b6019b2b8.pdf. Acesso em: 6 mar 2019.

SOUZA SANTOS, B. de (2019). O fim do império cognitivo: a afirmação das epistemologias do sul. Belo Horizonte, Autêntica.

SVAMPA, M. (2016). “Extrativismo neodesenvolvimentista e movimentos sociais. Um giro ecoterritorial rumo a novas alternativas?" In: DILGER, G.; LANG, M.; PEREIRA FILHO, J. (orgs.). Descolonizar o imaginário: debates sobre o pósextrativismo e alternativas ao desenvolvimento. São Paulo, Fundação Rosa de Luxemburgo.

TORRES, H.; MARQUES, E. (2001). Reflexões sobre a hiperperiferia: novas e velhas faces da pobreza no entorno metropolitano. Revista Brasileira de Estudos Urbanos e Regionais, n. 4, pp. 49-70.

TRINDADE JUNIOR, S. C. da (2019). “Confinamento, dispersão e difusão. Processos e configurações espaciais de uma metrópole em formação". In: TRINDADE JUNIOR, S. C. da; VELOSO DOS SANTOS, T. (orgs.). O urbano e o metropolitano em Belém. Rio de Janeiro, Consequência.

(2000). A natureza da urbanização na Amazônia e sua expressão metropolitana. Geografares. Vitória, v. 1, n. 1, pp. 117-129.

UFPA - Universidade Federal do Pará (2017). Trópico em movimento. Estudos revelam que a emissão de gás metano no Lixão do Aurá é equivalente à queima de 34 mil hectares de floresta. Publicado em 5 dez 2017. Portal UFPA. Disponível em: <https://www.portal.ufpa.br/index.php/ultimasnoticias2/7711-estudos-revelam-que-a-emissao-de-gas-metano-no-lixao-do-aura-e-equivalentea-queima-de-34-mil-hectares-de-floresta>. Acesso em: 8 dez 2018.

UNEP (2015). Global Waste Management Outlook (GWMO). United Nations Environment Programme/ ISWA - International Solid Waste Association. Disponível em: <https://www.unenvironment.org/ resources/report/global-waste-management-outlook>. Acesso em: 4 jan 2018.

VASCONCELOS JUNIOR, M. R. V; CORRÊA, R. do S. da S. (2017). Impactos Socioambientais Causados pelo Aterro Sanitário no Município de Marituba - PA. Disponível em: <https://repositorio.ufsc.br/ handle/123456789/180039> Acesso em: 13 dez 2018.

WALLERSTEIN, I. (1999). Impensar las ciencias sociales: límites de los paradigmas decimonónicos. Buenos Aires, Siglo XXI

WORLD BANK (2012). What a waste: a global review of solid waste management. Urban development series; knowledge papers no. 15. World Bank, Washington, DC. Disponível em: <https:// openknowledge.worldbank.org/handle/10986/17388> Acesso em: 12 fev 2018.

ZANETI, I. C. B.; MOURÃO SÁ, L; ALMEIDA, V. G. (2009). Insustentabilidade de produção de resíduos: a face oculta do sistema do capital. Revista Sociedade e Estado. Brasília, v. 24, n. 1, pp. 173192. 
